\title{
PENYULUHAN TENTANG CARA MENGATASI KECEMASAN IBU HAMIL MENJELANG PERSALINAN
}

\author{
Rika Oktapianti ${ }^{1}$, Dempi Triyanti ${ }^{2}$ \\ ${ }^{1,2}$ Sekolah Tinggi Ilmu Kesehatan Bina Husada Palembang \\ Email: ${ }^{1}$ Rika.oktapianti@yahoo.co.id, ${ }^{2}$ Demptriyanti89@gmail.com
}

\begin{abstract}
ABSTRAK
Kehamilan disebut suatu periode dimana seorang wanita membawa embrio (fetus) didalam rahimnya kehamilan manusia terjadi 40 minggu mulai waktu menstruasi terakhir dan kelahiran (38 minggu dari pembuahan). Berdasarkan Kemenkes RI 2015 Di Indonesia terdapat 373.000.000 orang ibu hamil, yang mengalami kecemasan dalam menghadapi persalinan ada sebanyak 107.000.000 orang $(28,7 \%)$. Sedangkan seluruh populasi di pulau sumatera terdapat $679.765 \mathrm{ibu}$ hamil, yang mengalami kecemasan dalam menghadapi persalinan sebanyak 355.873 orang $(52,3 \%)$. Tujuan pengabdian masyarakat ini adalah untuk mengetahui cara mengatasi kecemasaan ibu hamil menjelang persalinan. Metode yang dilakukan yaitu penyuluhan cara mengatasi kesemasan menjelang persalinan bagi peserta penyuluhan. Hasil yang diperoleh dalam kegiatan ini adalah para ibu hamil mengetahui tentang pengertian, penyebab kecemasan, tingkat kecemasan, faktor-faktor yang mempengaruhi kecemasan ibu hamil dalam menghadapi persalinan dan tekhnik untuk mengurangi rasa ketakutan pada saat persalinan. Serta memberikan dorongan bagi tenaga kesehatan dalam memberikan motivasi pada setiap konseling pada setiap konseling ibu hamil.
\end{abstract}

Kata kunci : Cemas, Persalinan

\begin{abstract}
Pregnancy is called a period in which a woman carries an embryo (fetus) in her womb. Human pregnancy occurs 40 weeks from the time of the last menstruation and birth (38 weeks from conception).Based on the 2015 Ministry of Health RI, in Indonesia there were 373 million pregnant women, who experienced anxiety in facing childbirth as many as $107,000,000$ people (28.7\%). While the entire population on the island of Sumatra there were 679,765 pregnant women, who experienced anxiety in facing childbirth as many as 355,873 people $(52.3 \%)$. The purpose of this community service is to find out how to overcome the anxiety of pregnant women before labor. The method used was counseling on how to overcome anxiety before delivery for counseling participants. The results obtained in this activity were that pregnant women knew about the meaning, causes of anxiety, levels of anxiety, the factors that influence the anxiety of pregnant women in facing labor and techniques to reduce anxiety before childbirth. As well as providing encouragement for health workers in providing motivation for every counseling on every counseling for pregnant women.
\end{abstract}

Keywords: Anxious, Labor 


\section{PENDAHULUAN}

Kehamilan merupakan sesuatu yang akan terjadi pada wanita yang produktif, tetapi ketidaktahuan mereka akan perilaku-perilaku, informasi-informasi yang berkaitan dengan organ reproduksi akan menimbulkan kekhawatiran tersendiri pada saat kehamilan. Ibu yang pertama kali hamil akan lebih sering kekhawatiran dan rasa cemas terhadap cerita yang diperolehnya pada saat hamil. Pada trimester ketiga, rasa khawatir menjelang persalinan ibu akan muncul karena pada trimester ini jika ibu memiliki rasa khawatir yang terlalu tinggi dapat menyebabkan resiko yang akan dialami oleh ibu seperti kelahiran bayi premature. Oleh karena itu, pada ibu hamil diharapkan tidak mengalami kekhawatiran yang berlebih terhadap kehamilannya ${ }^{1}$.

Usia Kehamilan trimester ketiga, rasa cemas ibu hamil semakin meningkat seiring dengan mendekatnya kelahiran bayi. Apalagi pada saat persalinan jika ibu hamil tidak mendapatkan motivasi dan support dari lingkungan dan keluarga khususnya suami, ibu akan mengalami rasa khawatir, cemas dan rasa takut yang tinggi, hal ini merupakan peringkat teratas yang paling sering dialami oleh ibu hamil ${ }^{2}$.

Pengalaman ibu yang melahirkan pertama kali dapat memberikan perasaan yang bercampur antara bahagia dan penuh kekhawatiran tentang apa yang akan dialami selama persalinan nanti. Rasa cemas tersebut bisa muncul karena bayangan tentang hal-hal yang menakutkan saat proses persalinan nanti, walaupun apa yang dibayangkan belum tentu terjadi. Situasi in idapat menimbulkan perubahan yang drastic pada ibu, bukan hanya fisik tapi psikologis juga ${ }^{3}$.

Berdasarkan laporan World Health Organization (WHO) diperkirakan diseluruh dunia terdapat sekitar 536.000 wanita meninggal dunia akibat masalah persalinan. Di Indonesia survey saat ini menunjukkan angka kematian ibu telah mengalami penuruna, dimana tahun 2016-2017 yaitu 307/100 ribu ibu melahirkan turun menjadi 226/100 ribu ibu melahirkan tahun 2012. Namun demikian, jika kita melihat kembali target SDGs tahun 2025 masih cukup jauh, dimana target yang diharapkan yaitu 125/100 ribu ibu melahirkan ${ }^{4}$.

Di Indonesia terdapat 373.000 .000 orang ibu hamil yang mengalami cemas dalam menghadapi persalinan ada sebanyak 107.000 .000 orang $(28,7 \%)$. Sedangkan seluruh populasi di pulau Sumatera terdapat 679.765 ibu hamil yang mengalami cemas dalam menghadapi persalinan 355.873 orang $(52,3 \%)^{5}$.

Faktor yang berhubungan dengan kecemasan yaitu pengetahuan, psikologi, ekonomi, pengalaman, dukungan keluarga serta dukungan suami. Ibu hamil dengan usia hamil yang beresiko dapat mengalami kelainan atau gangguan pada janin, sehingga dapat menimbulkan rasa khawatir pada saat menjelang persalinan ${ }^{6}$. 
Rasa cemas sangat berpengaruh terhadap kesejahteraan ibu hamil maupun janin yang didalam kandungan. Rasa cemas yang rendah pada ibu hamil dapat mengurangi gejala-gejala yang akan ditimbulkan pada saat hamil sehingga secara tidak langsung dapat mengurangi AKI dan AKB di Indonesia, sedangkan rasa cemas yang tinggi pada ibu dapat memperberat komplikasi yang terjadi dan meningkatkan $\mathrm{AKI}$ dan $\mathrm{AKB}^{7}$.

Tidak semua ibu menyadari bahwa aspek fisilogis dan psikologis adalah dua hal yang terkait saling mempengaruhi. Rasa cemas merupakan suatu keadaan normal yang mungkin di rasakan oleh setiap ibu yang mengalami tekanan atau perasaan yang sangat dalam sehingga dapat menyebabkan masalah psikologis ibu pada saat kehamilan. Penelitian di Indonesia menunjukkan bahwa setiap ibu hamil yang mengalami cemas yang tinggi dapat meningkatkan resiko kelahiran bayi tidak cukup bulan bahkan ada yang mengalami keguguran. Jika hal tersebut dibiarkan terjadi, maka AKI dan AKB akan semakin meningkat ${ }^{8}$.

Bidan sangat berperan penting dalam persalinan, sehingga sangat penting bidan bisa mengetahui rasa cemas yang dialami oleh ibu dan bidan juga harus mengetahui cara terbaik untuk mengatasi cemas pada saat persalinan. Kecemasan adalah perasaan takut yang tidak jelas dan tidak didukung oleh situasi. Individu yang merasa cemas akan tidak nyamamn atau takut, namun tidak mengetahui alasan kondisi tersebut terjadi. Kecemasan ini tidak memiliki stimulus yang jelas yang dapat diidentifikasi ${ }^{9}$.

Hasil penelitian Trisiani (2016) menunjukkan bahwa ibu pertama kali melahirkan yang mengalami kecemasan sedang sebesar $52,7 \%$ sedangkan yang mengalami kecemasan tinggi sebesar $57,8 \%$.

Hasil penelitian Heriani (2016) menunjukkan bahwa proporsi ibu primigravida yang mengalami kecemasan sebesar $72,2 \%$ sedangkan ibu hamil multigravida yang mengalami kecemasan sebesar $47,1 \%{ }^{10}$.

Penelitian Oktapianti (2021) di Praktik Mandiri Bidan (PMB) Wiwiet Wulandari menunjukkan hasil bahwa masih banyak ibu hamil yang mengalami rasa cemas hingga takut dalam kehamilannnya. Berdasarkan hasil penelitian ini maka penulis tertarik untuk melakukan pengabdian masyarakat dengan mensosialisasikan cara mengatasi kecemasan dalam menghadapi persalinan kepada ibu hamil yang berada di PMB Wiwiet Wulandari Palembang sebagai upaya mencegah angka kesakitan pada ibu hamil ${ }^{11}$.

\section{METODE}

Pengabdian masyarakat dilakukan di Praktik Mandiri Bidan Wiwiet Wulandari Palembang pada tanggal 17 Juni 2021, dengan tahapan dan metode pelaksanaan sebagai berikut : 
1. Sosialisasi dan Perijinan

Tahap awal yang harus dilakukan adalah sosialisasi dan perijinan kepada pihak praktik mandiri bidan wiwiet wulandari untuk mendapatkan persetujuan waktu dan tempat, selanjutnya melakukan sosialisasi kepada pihak terkait untuk mengumpulkan ibu hamil untuk menghadiri sosialisasi cara mengatasi rasa cemas menjelang persalinan dengan mengikuti protokol kesehatan.

2. Persiapan alat dan sarana serta media

Alat dan sarana yang dipersiapkan pada kegiatan ini adalah media penyuluhan antara lain power point dan leaflet.

3. Penyuluhan cara mengatasi rasa cemas menjelang persalinan.

Ibu hamil dikumpulkan dalam satu ruangan dengan memperhatikan protokol kesehatan. Penyuluhan diberikan sejelas - jelasnya dengan memberikan kesempatan bertanya bagi para peserta penyuluhan yang belum paham.

4. Proses evaluasi dilakukan kepada para peserta penyuluhan dilakukan dengan memberikan pertanyaan sesuai dengan materi yang telah diberikan dan peserta bisa menjawab dari pertanyaan-pertanyaan yang diberikan oleh penyuluh.

\section{HASIL DAN PEMBAHASAN}

Peserta mengikuti penyuluhan dengan semangat dan antusias. Peserta penyuluhan sebanyak 14 orang yang terdiri dari 14 ibu hamil. Peserta datang tepat waktu dan memperhatikan protokol kesehatan. Penyuluhan berjalan lancar. Penggunaan media seperti laptop, LCD dan leaflet membantu peserta penyuluhan dalam memahami cara mengatasi rasa cemas menjelang persalinan. Materi juga disampaikan dengan sederhana menyesuaikan dengan tingkat pendidikan peserta penyuluhan.

Beberapa ibu hamil menceritakan pengalaman hamilnya. Mereka mengatakan memiliki perasaan cemas menjelang persalinan seperti meningkatnya rasa panik, cemas, khawatir dan gelisah ketika menghadapi persalinannya tidak bisa mengedan, jika melahirkan dalam kondisi patologis dan khawatir jika yang dilahirkan cacat. Namun setelah diberi pengetahuan tentang tahapan persalinan dan cara mengatasi rasa nyeri persalinan. Rasa takut yang disebabkan oleh kurangnya pengetahuan ibu dalam tahapan proses persalinan dapat berkurang karena ibu sudah lebih tahu proses bagaimana tahapan persalinan nanti dan tahu cara mengurangi rasa nyeri persalinan..

Berdasarkan hasil evaluasi yang diberikan melalui post test didapatkan bahwa pengetahuan peserta penyuluhan sudah memahami tahapan proses persalinan dan cara mengurangi rasa cemas dan nyeri pada saat menjelang persalinan. Hasil kegiatan ini 
mampu mengubah pengetahuan ibu, karena ibu sudah memahami dan sudah bisa lebih nyaman pada kehamilannya sehingga tingkat kecemasan yang dialami berkurang.

\section{KESIMPULAN}

Sosialisasi dan edukasi tentang cara mengatasi cema menjelang persalinan sebagai upaya mencegah ibu memiliki rasa khawatir selama persalinan, dengan penyuluhan ini ibu nanti bisa mengahadapi proses persalinan yang lebih nyaman. Saran untuk pihak Praktik Mandiri Bidan agar dapat meningkatkan antenatal care untuk mempersiapkan ibu hamil secara fisik dan mental dalam menghadapi persalinan. Sehingga dapat mengurangi kecemasan selama kehamilan.

\section{UCAPAN TERIMA KASIH}

Kami ucapkan kepada warga dan pihak Praktik Mandiri Bidan Wiwiet Wulandari yang telah bekerja sama dengan baik sehingga pengabdian masyarakat ini berjalan dengan lancar dan bermanfaat.

\section{REFERENSI}

Amalia. 2015. Kecemasan Ibu Menanti Persalinan. Titian Amalia. Jakarta Heriani. 2016. Kecemasan Dalam Menjelang Persalinan Ditinjau Dari Paritas, Usia dan Tingkat Pendidikan. Jurnal Aisyiyah: Jurnal Ilmu Kesehatan, 1 (2), 01-08

Karlsdottir, S. I, Halldorsdottir S, \& Lundren, I 2014. The third paradigm in labour pain preparation and management: the childbearing woman's paradigm. Scandinavian Journal of Caring Sciences

Kemenkes RI. 2015. KIA Jakarta: Sub Dinas Kesga dan Gizi

Maghfiroh. 2015. Faktor-Faktor Yang Berhubungan Dengan Kecemasan Yaitu Pengetahuan, Ekonomi, Pengalaman, Dukungan keluarga Serta Dukungan Suami

Oktapianti, Rika dan Triyanti, Dempi. Faktor-Faktor Yang Berhubungan Dengan Kecemasan Ibu Hamil menjelang Persalinan Di praktik Mandiri Wiwiet Wulandari Palembang

Rukiyah, Ai Yeyeh. 2016. Asuhan Kebidanan Kehamilan. Trans Info Medika. Jakarta

Shodiqoh. R. Eka dan Syahrul. F. 2014. Perbedaan Tingkat Kecemasan Dalam Menghadapi Persalinan Antara Primigravida Dan Multigravida. Jurnal Berkala Epidemiologi. Volume 2 Nomor 1, Januari 2018, Hlm. 141-150

Trisiani, D, Hikmawati, R. 2016. Hubungan Kecemasan Pada Ibu Hamil Terhadap Kejadian Preeklampsia Di RSUD Malajaya Kab. Bandung periode Bulan januari-Agustus 
WHO.2019(AKI).http://www.who.int/gho/publicationworld_health_statistic/2016 en/, Diakses 12 Maret 2021)

Wulandari. 2015. Efektivitas Senam Hamil Sebagai Pelayanan Prenatal Dalam menurunkan Kecemasan Menghadapi Persalinan Pertama. Fakultas Psikologi Universitas Airlangga 